Journal of Polymer Science

A PERUSAL of any of the published journals dealing with chemical and physical researches reveals an increasing number of papers devoted to matters concerning high polymers. Before the War, the tendency was not specially marked, but in the past seven years the growth of the purely academic side of the subject has increased significantly. This high-polymer chemistry might normally be regarded as a branch of classical colloid chemistry; but it has now outgrown this field and deserves a place of its own in chemical literature. To cater for those who wish to publish and to read recent advances in this relatively new branch of chemistry, a new Journal of Polymer Research has just made its appearance. It is pub. lished by Inter-Science Publishers, New York, and edited by P. M. Doty, H. Mark and C. C. Price, who will no doubt ensure that the quality of the papers submitted will reach a high standard. Similar ideas were in the minds of the Elsevier Co. of Amsterdam, and plans had actually been made to issue another journal on polymer science edited by R. Houwink. It is to the credit of both these publishers that they have seen their way to amalgamate the two journals, the editorial boards having joined forces in this international experiment. The subsequent issues will be under the title of Journal of Polymer Science published jointly by Interscience and Elsevier. The first number of the journal contains original papers by Huggins, Mark, K. H. Meyer, C. C. Price and others well qualified to write on matters concerning high polymers. If the standard of the first issue is maintained, there is little doubt that the journal will become a recognized medium for reporting on advances in high-polymer research.

\section{Restoration of Science in Austria}

A LeAFlet on "Science in Austria", presented on the occasion of the meeting of British men of science and the Association of Austrian Chemists, Engineers and Scientific Workers in Great Britain in support of the restoration of science in Austria, on November 3, 1945 (seo Nature, Jan. 12, 1946, p. 53), includes a survey of the present position (from the Association, 133 Hatherley Court, London, W.2. Pp. 28). It refers to material destruction due to the War-heavy damage to the main buildings of the University in Vienna, the loss of a large part of the books of the University Library, and the total loss of the Institute of Experimental Biology are mentioned -and of moral devastation due to Nazi rule and resistance to the Germans in the universities. The Provisional Government and the Secretary for Education are attributing the greatest importance to repairing the intellectual damage of seven years of Nazi rule. A short survey of past scientific achieverments in Austria gives an impressive picture of our debt to Austria in physics, radioactivity, chemistry, zoology and botany, even in the difficult period through which this small and impoverished country passed between the world wars. The concluding part of the pamphlet, "What Austrian Scientists Desire", expresses a hope for early restoration of contact between Austrian and Allied men of science, and includes a note by Emil Abel on the pioneers of physical chemistry in Austria, a tribute by F. Eirich to the work of H. Mark and W. Pauli, sen., in colloid chemistry, and other notes on Austrian work by L. Janossy (on cosmic rays), St. Jellinek (electro-pathology), H. Steiner (physical chemistry) and K. Weissenberg (on Guido Holzknecht's work on the application of $\mathrm{X}$-rays to medicine).

\section{Blindness of the Newly Born}

EvERYoNe who is interested in the welfare of the young, especially those who are interested in the prevention of blindness or impaired sight in the newly born or very young, should read the monograph entitled "Ophthalmia Neonatorum", by Prof. Arnold Sorsby (Institute of Ophthalmology Monographs No. 1. Pp. 1-66. London: Hamish Hamilton Medical Books, Ltd., 1945.) A note on his views on the world-distribution and causes of blindness in young and old alike has already been published in Nature $(153,383$; 1944), and Prof. Sorsby has since supplemented them by a striking article on blindness in the British Commonwealth (Brit. Med. J., 557, Oct. 27 ; 1945). In the present monograph he summarizes existing knowledge on one aspect of the general problem of blindness and impaired sight, but it is an aspect which is of very great importance. If his monograph suggests that impaired vision and blindness due to ophthalmia in the newly born is, as Sir Allen Daley says in his foreword, "well on the way to extinction", it also suggests that ophthalmia of the newly born is possibly "no less frequent to-day than it was 25 or 40 years ago". The statistics pub. lished in the monograph certainly leave no cause for complacency, although the results of compulsory notification and treatment, notably treatment with sulphonamides and penicillin, have been so remarkably good. The use of penicillin in ophthalmology is discussed in a leading article in the British Medical Journal (17, Jan. 5; 1946). Sir Allen Daley says that no preventable case of blindness should occur, and those who are familiar with recent developmente in ophthalmology will agree that vigorous efforts are being made to attain this ideal.

\section{Polarographic Analysis applied to Cancer Diag- nosis}

Is 1937 Dr. R. Brdička followed up an earlier (1933) observation that the sulphydryl group in proteins causes a distinct catalytic effect on polarographic current-voltage curves, by applying it to diagnose cancer through the effect the disease has upon the proteins in the blood. The results were presented to the Czech Academy of Sciences (37, 17 ; 1937); but publication was delayed and it is only recently that the account has reached Great Britain. It was found that carcinomatic sera give definitely smaller polarographic effects than normal sera. The method consisted in taking 0.3 c.c. of centrifuged blood serum and adding 0.15 c.c. of normal potassium hydroxide solution and $0 \cdot 3$ c.c. of potassium iodoacetate (which reacts with the sulphydryl group in proteins). After standing an hour, amounts of 0.1 c.c. of the mixture are taken out at intervals and added to 5 c.c. of a cobalt chloride solution containing $8 \times 10^{-4}$ molar cobalt chloride, $0 \cdot 1$ normal ammonium chloride and 0.1 normal ammonia. The polarographic curves of these solutions are recorded, using a dropping mercury cathode, the anode being the mercury layer below the solution. In this way 67 cases were examined; 32 gave the abnormally low (carcinomatic) protein effect, in agreement with the clinical conclusions.

\section{Quality Control for Engineers}

"A Frrst Guide to Quality Control for Engineers" (London : H.M. Stationery Office, 1945. Pp. 38. 1 . net), compiled in 1943 by Dr. E. H. Sealy of tho Ministry of Supply Advisory Service on Quality Con- 